medRxiv preprint doi: https://doi.org/10.1101/2020.05.23.20111450; this version posted May 26, 2020. The copyright holder for this preprint

(which was not certified by peer review) is the author/funder, who has granted medRxiv a license to display the preprint in perpetuity.

It is made available under a CC-BY-NC-ND 4.0 International license .

\title{
The Outcome Impact of Early vs Late HFNC Oxygen Therapy in Elderly Patients with
}

\section{COVID-19 and ARDS}

Liehua Deng $^{1 *+}$, Shaoqing Lei ${ }^{2 *}$, Fang Jiang ${ }^{3 *}$, David A. Lubarsky ${ }^{4}$, Liangqing Zhang ${ }^{5}$, Danyong Liu $^{5}$, Conghua Han ${ }^{6}$, Dunrong Zhou ${ }^{7}$, Zheng Wang ${ }^{8}$, Xiaocong Sun ${ }^{1 ; 9}$, Yuanli Zhang ${ }^{1}$, Chi Wai

Cheung $^{3}$, Sheng Wang ${ }^{10}$, Zhong-yuan $\mathrm{Xia}^{2}$, Richard L Applegate 2nd ${ }^{4}$, Hong Liu ${ }^{4 \#}$, Jing Tang ${ }^{5 \#+}$, Zhengyuan Xia ${ }^{3 ; 4 ; 5 \#+}$

${ }^{1}$ Department of Critical Care Medicine of affiliated hospital of Guangdong Medical University, Guangdong, China; ${ }^{2}$ Department of Anesthesiology, Renmin Hospital of Wuhan University, Wuhan, China; ${ }^{3}$ Department of Anesthesiology, The University of Hong Kong, Hong Kong, China; ${ }^{4}$ Department of Anesthesiology and Pain Medicine, University of California Davis Health, Sacramento, CA, USA; ${ }^{5}$ The Department of Anesthesiology, Affiliated hospital of Guangdong Medical University, Zhanjiang, Guangdong, China; ${ }^{6}$ Department of Critical Care Medicine of Xiantao first people's Hospital of Xiantao City, Hubei, China; ${ }^{7}$ Department of Critical Care Medicine of people's Hospital of Yangjiang City, Guangdong, China; ${ }^{8}$ Department of Critical Care Medicine of people's Hospital of Maoming City, Guangdong, China; ${ }^{9}$ Chinese Medicine Hospital of Shishou City, Hubei, China; ${ }^{10}$ Department of Anesthesiology, Guangdong provincial people's Hospital, Guangdong Academy of Medical Sciences, Guangzhou, Guangdong, China

*Drs. Deng, Lei and Jiang contributed equally as co-first authors

\#Drs. H. Liu, J. Tang and Z. Xia contributed equally as co-last authors.

+Joint corresponding authors

Dr. Zhengyuan Xia

Department of anesthesiology, the University of Hong Kong, Hong Kong, China; and Department of Anesthesiology, Affiliated hospital of Guangdong Medical University, China Email: zyxia@hku.hk

Dr. Jing Tang

Department of Anesthesiology, Affiliated hospital of Guangdong Medical University, China Email: tanglitangjing@126.com

Dr. Liehua Deng

Department of Critical Care Medicine of affiliated hospital of Guangdong Medical University, Guangdong, China; Email: glinson@126.com 
medRxiv preprint doi: https://doi.org/10.1101/2020.05.23.20111450; this version posted May 26, 2020. The copyright holder for this preprint (which was not certified by peer review) is the author/funder, who has granted medRxiv a license to display the preprint in perpetuity.

It is made available under a CC-BY-NC-ND 4.0 International license .

\begin{abstract}
Coronavirus disease-2019 (COVID-19) has rapidly spread worldwide. High-flow nasal cannula therapy (HFNC) is a major oxygen supporting therapy for severely ill patients, but information regarding the timing of HFNC application is scarce, especially in elderly patients. We retrospectively analyzed the clinical data of 110 elderly patients ( $\geq 65$ years) who received HFNC from Renmin Hospital of Wuhan University, People's Hospital of Xiantao City and Chinese Medicine Hospital of Shishou City in Hubei Province, China, and from Affiliated Hospital of Guangdong Medical University, People's Hospital of Yangjiang City, People's Hospital of Maoming City in Guangdong Province, China.

Of the 110 patients, the median age was 71 years (IQR, 68-78) and 59.1\% was male. Thirty-eight patients received $\mathrm{HFNC}$ when $200 \mathrm{mmHg}<\mathrm{PO}_{2} / \mathrm{FiO}_{2} \leq 300 \mathrm{mmHg}$ (early $\mathrm{HFNC}$ group), and 72 patients received $\mathrm{HFNC}$ treatment when $100 \mathrm{mmHg}<\mathrm{PaO}_{2} / \mathrm{FiO}_{2} \leq 200 \mathrm{mmHg}$ (late $\mathrm{HFNC}$ group). Compared with the late HFNC group, patients in the early HFNC group had a lower likelihood of developing severe ARDS, longer time from illness onset to severe ARDS and shorter duration of viral shedding after illness onset, as well as shorter lengths of ICU and hospital stay. Twenty-four patients died during hospitalization, of whom 22 deaths (30.6\%) were in the late HFNC group and $2(5.3 \%)$ in the early HFNC group. It is concluded that the Prognosis was better in severely ill elderly patients with COVID-19 receiving early compared to late HFNC. This suggests HFNC could be considered early in this disease process.
\end{abstract}

Key words: COVID-19; High-flow nasal cannula therapy; ARDS; Elderly patients 
medRxiv preprint doi: https://doi.org/10.1101/2020.05.23.20111450; this version posted May 26, 2020. The copyright holder for this preprint (which was not certified by peer review) is the author/funder, who has granted medRxiv a license to display the preprint in perpetuity.

\section{Introduction}

Coronavirus disease-2019 (COVID-19) caused by severe acute respiratory syndrome coronavirus 2 (SARS-CoV-2), was first reported in December 2019 in Wuhan, Hubei, China, but has rapidly spread worldwide.[1] Since initial detection of the virus, more than 2,626,000 cases of COVID19 have been confirmed worldwide, with more than 181,000 deaths as of April 24, 2020. COVID-19 is more likely to affect elderly patients with comorbidities, and can result in severe or fatal respiratory diseases such as acute respiratory distress syndrome (ARDS).[2] Initial reports from China[3], Italy[4] and the United States[5] suggested high mortality for elderly and critically ill patients with COVID-19. No specific therapeutic agents or vaccines for COVID-19 are available, although several antiviral medications such as remdesivir and favipiravir are under investigation. [6,7]

Patients with severe illness may develop dyspnea and hypoxemia within one week after the onset of COVID-19 and may quickly progress to ARDS,[2] a major cause of death in patients with COVID-19.[8] Thus, respiratory support and intensive care management are vital to saving lives. Reports showed that both conventional oxygen therapy and non-invasive ventilation (NIV), such as NIPPV (non-invasive positive pressure ventilation), are commonly used in COVID-19 patients to improve oxygenation and reduce the possibility of intubation.[9' 10] However, the risk of airborne transmission with NIPPV is a major concern, while that for high flow nasal cannula therapy (HFNC) is judged minimal.[11] A guideline for the management of critically ill adults with COVID-19 published in JAMA March 26, 2020 recommended the use of HFNC relative to NIPPV in the circumstance of acute hypoxemic respiratory failure despite conventional oxygen therapy.[11] However, evidence is lacking regarding optimal timing to apply HFNC. In this study, we report the clinical characteristics of elderly ( $\geq 65$ years) patients with COVID-19 who developed ARDS on or shortly after admission and compared outcomes of patients who started HFNC at different stages of ARDS. 
medRxiv preprint doi: https://doi.org/10.1101/2020.05.23.20111450; this version posted May 26, 2020. The copyright holder for this preprint (which was not certified by peer review) is the author/funder, who has granted medRxiv a license to display the preprint in perpetuity.

\section{Methods}

\section{Study design and participants}

This retrospective cohort study included elderly patients ( $\geq 65$ years) from Renmin Hospital of Wuhan University, People's Hospital of Xiantao City and Chinese Medicine Hospital of Shishou City in Hubei Province, China, and from Affiliated Hospital of Guangdong Medical University, People's Hospital of Yangjiang City, People's Hospital of Maoming City in Guangdong Province, China. All elderly patients who were diagnosed with severe COVID-19 according to WHO interim guidance, and those who were treated with HFNC between January 14, 2020 (when the first patients were admitted in these hospitals) and March 5, 2020, were included in the present study. Due to the lack of understanding of this new disease, the timing of HFNC treatment was uncertain. In this retrospective study, of 110 HFNC-treated patients, 38 received HFNC treatment when $200 \mathrm{mmHg}<\mathrm{PO}_{2} / \mathrm{FiO}_{2} \leq 300 \mathrm{mmHg}$ (early $\mathrm{HFNC}$ group), while 72 were first treated with conventional oxygen therapies (e.g., low flow nasal catheter ventilation) and then HFNC when $100 \mathrm{mmHg}<\mathrm{PO}_{2} / \mathrm{FiO}_{2} \leq 200 \mathrm{mmHg}$ (late HFNC group). HFNC was started from low levels and gradually titrated to $60 \mathrm{~L} / \mathrm{min}$ for patients without obvious complaint of chest distress or shortness of breath. However, for patients who were short of breath (e.g., respiratory rate $>30 / \mathrm{min}$ ) the flow rates were commenced at $60 \mathrm{~L} / \mathrm{min}$. The goal of oxygen therapy was to maintain the oxygen saturation $\left(\mathrm{SpO}_{2}\right)$ at $93 \%-96 \%$, which is in keeping with the recent guideline recommendation of a reasonable $\mathrm{SpO} 2$ range of $92-96 \%$ for patients receiving oxygen .[12]

This study was reviewed and approved by the Medical Ethical Committee of participating institutes (PJ2020-005), and the informed consent was waived by the Medical Ethical Committee. 
medRxiv preprint doi: https://doi.org/10.1101/2020.05.23.20111450; this version posted May 26, 2020. The copyright holder for this preprint (which was not certified by peer review) is the author/funder, who has granted medRxiv a license to display the preprint in perpetuity.

\section{Data Collection}

Patients' medical records were reviewed and epidemiological, clinical, laboratory, and radiological characteristics and treatment and outcomes data were obtained with data collection forms. Two research investigators (LD and SL) independently reviewed the data collection forms to verify accuracy.

We collected data on age, sex, exposure history, comorbidities (e.g., hypertension, diabetes, malignancy, cardiovascular disease, cerebrovascular disease, chronic pulmonary disease, chronic kidney disease), chest CT images, signs and symptoms (e.g., fever, fatigue, dry cough, dyspnea), time of first symptom to dyspnea, ARDS and ICU admission, vital signs (heart rate, respiratory rate, blood pressure) and laboratory values (e.g., white blood cell count, neutrophil count, lymphocyte count, procalcitonin concentration, arterial blood gas analysis, fraction of inspired oxygen $\left(\mathrm{FiO}_{2}\right)$, partial pressure of arterial oxygen $\left(\mathrm{PaO}_{2}\right)$, and lactate concentration) on hospital admission and disease progression, treatments (e.g., oxygen support, antiviral therapy, antibiotic therapy, glucocorticoids, immunoglobulin), complications (e.g., septic shock, ARDS, secondary infection), and discharge/death. The numbers of patients requiring mechanical ventilation, the numbers of patients requiring $\mathrm{FiO}_{2}=100 \%,>80 \%$ and $>60 \%$ for more than 72 hours continuously, length of ICU stay, and length of stay (LOS) were also collected.

\section{Outcomes}

The primary outcome was in-hospital mortality. Secondary outcomes included incidence of severe ARDS, the numbers of ICU admission and patients requiring mechanical ventilation. The ICU admission standard is patients require invasive mechanical ventilation, or have shock or other organ failure that need ICU monitoring and treatment.[13 14] ARDS was defined as acute 
medRxiv preprint doi: https://doi.org/10.1101/2020.05.23.20111450; this version posted May 26, 2020. The copyright holder for this preprint (which was not certified by peer review) is the author/funder, who has granted medRxiv a license to display the preprint in perpetuity.

It is made available under a CC-BY-NC-ND 4.0 International license .

onset hypoxemia $\left(\mathrm{PaO}_{2} / \mathrm{FiO}_{2}\right.$ : mild $\mathrm{ARDS},>200$ to $\leq 300 \mathrm{mmHg}$; moderate $\mathrm{ARDS},>100$ to $\leq 200 \mathrm{mmHg}$; severe ARDS, $\leq 100 \mathrm{mmHg}$ ) with bilateral pulmonary opacities on chest imaging not fully explained by other disease according to the Berlin definition.[15] Secondary infection was defined when patients showed clinical symptoms or signs of bacteremia and a positive culture of a new pathogen obtained from sputum or blood samples after admission.[13] Acute cardiac injury was identified when the hypersensitive troponin I and creatine kinase-MB were above the $99 \%$ upper reference limit or new abnormalities were shown in electrocardiography and echocardiography.[13] Acute kidney injury (AKI) was defined according to KDIGO criteria.[16]

\section{Statistical analysis}

Continuous variables were presented as mean with standard deviation (SD) when normally distributed and compared by independent sample $t$ test, or expressed as median with interquartile range (IQR) if non-normally distributed and compared by Mann-Whitney U test. Categorical variables were expressed as n (\%) and compared by Pearson's chi-square or Fisher's exact test between early HFNC and late HFNC groups. A two-sided $\alpha$ of less than 0.05 was considered statistically significant. All statistical analyses were performed with the SPSS (version 25) software.

\section{Results}

A total of 638 elderly patients ( $\geq 65$ years) with confirmed SARS-CoV-2 infection were admitted to participating hospitals during the defined study time period. Of these, 502 patients who did not receive HFNC treatment were excluded, as were 19 patients due to missing key information in their medical records, and 7 patients who had cardiac arrest within 24 hours after admission. 
medRxiv preprint doi: https://doi.org/10.1101/2020.05.23.20111450; this version posted May 26, 2020. The copyright holder for this preprint (which was not certified by peer review) is the author/funder, who has granted medRxiv a license to display the preprint in perpetuity. It is made available under a CC-BY-NC-ND 4.0 International license .

Thus, a total of 110 patients were included in our study. Of these 110 patients, 38 patients received early HFNC treatment, and 72 patients received late HFNC treatment.

The median age of the 110 patients was 71 (IQR 68-78; range 65 to 89) years, and most $(65[59.1 \%)])$ were male (Table 1). Eighty-seven (79.1\%) patients had underlying comorbidities, 1.3 comorbidities per patient on average. The most common comorbidities were hypertension (57 [51.8\%]), cardiovascular disease (27 [24.5\%]), chronic pulmonary disease (22 [20\%]) and diabetes $(20[18.2 \%])$. The most common symptoms on admission were fever (105 [95.5\%]), cough (65 [59.1\%]), weakness (23 [20.9\%]), and sputum production (22 [20\%]) Table 1). The most common abnormal laboratory findings were lymphocytopenia, increased C-reactive protein, and decreased CD3, CD4 and CD8 counts on hospital admission (Table 1). The overall median $\mathrm{SPO}_{2}$ was $95 \%$ (IQR 93-98\%) on admission, and the median ratio of $\mathrm{PaO}_{2} / \mathrm{FiO}_{2}$ was $238 \mathrm{mmHg}$ (IQR 221-277). There were no significant differences in admission $\mathrm{SPO}_{2}$ or $\mathrm{PaO}_{2} / \mathrm{FiO}_{2}$ between early and late $\mathrm{HFNC}$ groups. Both $\mathrm{SpO}_{2}$ and $\mathrm{PaO}_{2} / \mathrm{FiO}_{2}$ ratio at initiation of $\mathrm{HFNC}$ were higher and the time from admission to HFNC treatment was shorter in the early HFNC group (Table 1).

All patients showed bilateral lung involvement on chest CT scan at admission, including consolidation, ground-glass opacity, interstitial lesions, and exudative lesions (figure 1). Patients who received early HFNC had a lower likelihood of developing severe pneumonia, manifested as more than $50 \%$ increase in pneumonitis foci on chest CT scan during disease progression (Table 2).

All patients received antiviral medications (lopinavir or ritonavir), and 66 (60\%) patients also received antibiotics. Thirty-eight $(34.5 \%)$ patients required prone ventilation, $24(21.8 \%)$ received non-invasive ventilation, and $42(38.2 \%)$ patients required invasive mechanical 
medRxiv preprint doi: https://doi.org/10.1101/2020.05.23.20111450; this version posted May 26, 2020. The copyright holder for this preprint (which was not certified by peer review) is the author/funder, who has granted medRxiv a license to display the preprint in perpetuity. It is made available under a CC-BY-NC-ND 4.0 International license .

ventilation, of whom 7 received extracorporeal membrane oxygenation as rescue therapy. Common complications among the 110 patients included secondary infection (51 [46.3\%]), severe ARDS (42 [38.2\%]), septic shock (18 [16.4\%]), acute cardiovascular injury (13 [11.8\%]), AKI (6 [5.4\%]), and cardiac arrest (3 [2.7\%]) (table 2). The patients who received early HFNC were less likely to have secondary infection or severe ARDS, and less likely to receive prone position ventilation and invasive mechanical ventilation than the patients who receive late HFNC.

Major laboratory markers and SOFA score were tracked from hospital admission (figure 2). Lymphocyte count was higher in patients who received early HFNC during hospitalization. Lactate dehydrogenase level did not differ between these two groups on day 3 after admission, but continued to increase in the late HFNC group and was significantly higher on day 9 after admission and onwards. Both the levels of D-dimer and C-reactive protein were significantly lower throughout the clinical course in patients who received early HFNC. Lactate concentration and SOFA score were similar between groups on day 3 after admission. Patients who received early HFNC showed lower lactate concentration on day 15 and lower SOFA score on day 9 after admission and onwards (figure 2).

Of the 110 patients who received $\mathrm{HFNC}, 40$ (36.4\%) patients required more than $60 \% \mathrm{FiO}_{2}$, $23\left(22.7 \%\right.$ ) patients required $\mathrm{FiO}_{2}$ more than 80\%, and $4(3.6 \%)$ patients required $100 \% \mathrm{FiO}_{2}$ (table 1). All 22 patients in the late HFNC group who died during hospitalization received $\mathrm{FiO}_{2}>$ $60 \%$ for more than 72 hours continuously (table 3 ). The numbers of patients who required higher than $60 \% \mathrm{FiO}_{2}$ and those who required more than $80 \% \mathrm{FiO}_{2}$ were smaller in the early $\mathrm{HFNC}$ group. $\mathrm{FiO}_{2}$ and $\mathrm{PO}_{2} / \mathrm{FiO}_{2}$ were tracked during hospitalization. As shown in figure 3, baseline $\mathrm{FiO}_{2}$ and $\mathrm{PaO}_{2} / \mathrm{FiO}_{2}$ were similar between the two groups. The patients in the early HFNC group 
medRxiv preprint doi: https://doi.org/10.1101/2020.05.23.20111450; this version posted May 26, 2020. The copyright holder for this preprint (which was not certified by peer review) is the author/funder, who has granted medRxiv a license to display the preprint in perpetuity. It is made available under a CC-BY-NC-ND 4.0 International license .

showed higher ratio of $\mathrm{PaO}_{2} / \mathrm{FiO}_{2}$ on day 3 after admission, and required lower $\mathrm{FiO}_{2}$ on day 6 after admission and onwards.

The median time from illness onset to ICU admission was 11 days (IQR 8-14), and 12 days (IQR 11-15) to severe ARDS. The length of ICU stay was 17 days (IQR 12-22), LOS was 27 days (IQR 16-32), and duration of viral shedding after illness onset was 16 days (IQR 13-21). Patients who received early HFNC were less likely to admit to ICU, less likely to stay in ICU longer than 7 days, had less chance to develop severe ARDS and had longer time from COVID19 onset to severe ARDS (if any). Duration of viral shedding after illness onset and length of ICU and hospital stay were shorter in the early HFNC group. A total of 86 (78.2\%) patients had been discharged, and $24(21.8 \%)$ patients had died. The mortality in late HFNC group was higher than that in early HFNC (22 [30.6\%] vs. 2 [5.3\%]) as shown in Table 2 and Figure 3C.

\section{Discussion}

This report, presents the outcomes of 110 severely ill elderly COVID-19 patients who received oxygen therapy with HFNC. Mortality was lower (5.3\%) in 38 patients who received HNFC treatment at the mild ARDS stage, compared to $30.6 \%$ in 72 patients in whom HNFC treatment was started at the moderate ARDS stage. The mortality rate in this study was lower than that reported from a multi-national study regarding the mortality for patients with ARDS, which was $34.9 \%$ and $40.3 \%$ respectively for those with mild or moderate ARDS.[17] An early report from China[3] and a recent report from the United States[5] reported $61.5 \%$ and $50 \%$ mortalities respectively for critically ill patients with COVID-19, while the mortality for critically ill patients aged 60 years or older was as high as 70.3\%.[3]

HFNC, as an innovative and effective modality for oxygen therapy, delivers titratable oxygen 
medRxiv preprint doi: https://doi.org/10.1101/2020.05.23.20111450; this version posted May 26, 2020. The copyright holder for this preprint (which was not certified by peer review) is the author/funder, who has granted medRxiv a license to display the preprint in perpetuity. It is made available under a CC-BY-NC-ND 4.0 International license .

up to 60 liters/minutes with heating and humidification to produce a low-level positive endexpiratory pressure and to achieve $\mathrm{FiO}_{2}$ as high as 95-100\%.[9] $\mathrm{HFNC}$ has been shown to reduce the risk of requiring more advanced ventilation and relieve dyspnea better than conventional oxygen therapy and has been suggested as a first-line therapy even before making a clear diagnosis for dyspnea.[10] In our study, $10.5 \%$ patients in the early HFNC group converted to invasive mechanic ventilation, which is in contrast to the $52.7 \%$ in the late HFNC group (Table 2). These findings can be compared to other published reports. A cohort study in 17 COVID-19 patients indicated starting $\mathrm{HFNC}$ when $\mathrm{PaO}_{2} / \mathrm{FiO}_{2}>200$ reduced the need of mechanical ventilation, although the impact on mortality was not reported.[18] Starting HFNC or invasive mechanical ventilation at a relatively late stage of disease severity such as moderate to severe ARDS may prompt the physician to apply high $\mathrm{FiO}_{2}$. Critically ill patients with COVID-19 in the Seattle region[5] had reported 50\% mortality at the time of data cut off with several patients continuing to receive mechanical ventilation in the ICU. In the study,[5] the initial median $\mathrm{FiO}_{2}$ on day 1 of mechanical ventilation was $90 \%$ (IQR 70-100\%), and the $\mathrm{FiO}_{2}$ decreased to $60 \%$ (IQR 50-70\%) on day 3 but no further information was provided about $\mathrm{FiO}_{2}$ afterwards. It is possible that the $\mathrm{FiO}_{2}$ had to be readjusted to higher levels due to the subsequent difficulty in reaching targeted $\mathrm{PaO}_{2}$ and/or $\mathrm{PaO}_{2} / \mathrm{FiO}_{2}$. High oxygen mediated oxidative lung damage[19] may further exacerbate oxygenation, which may paradoxically push for the need of higher $\mathrm{FiO}_{2}$. In addition, oxidative stress during respiratory viral infection may also exacerbate a "cytokine storm".[20] In the late $\mathrm{HFNC}$ group, the required $\mathrm{FiO}_{2}$ increase over time we found (Figure 3) was coincident with progressive increases of D-dimer and C-reactive protein (Figure 2), indicators of inflammation that could be related to a relatively higher mortality rate in the late HFNC group. 
medRxiv preprint doi: https://doi.org/10.1101/2020.05.23.20111450; this version posted May 26, 2020. The copyright holder for this preprint (which was not certified by peer review) is the author/funder, who has granted medRxiv a license to display the preprint in perpetuity. It is made available under a CC-BY-NC-ND 4.0 International license .

Evidence shows that liberal oxygen therapy increases mortality without improving other outcomes and that supplemental oxygen might become unfavorable above a $\mathrm{SpO}_{2}$ range of 9496\%.[21] A multicenter study of critically ill patients with the Middle East Respiratory Syndrome (MERS) related to MERS-CoV infection showed that non-survivors received significantly higher FiO2 than survivors on ICU day 1.[22] Thus, despite the generally accepted normal range of $\mathrm{PaO}_{2} 80$ - $100 \mathrm{mmHg}$ breathing room air at sea level in healthy young adults, we took into consideration the relatively lower reference values for $\mathrm{PaO}_{2}$ in the elderly compared to young adults as well as gender differences.[23,24] Previous studies showed that in elders over 70 years old the normal $\mathrm{PaO}_{2}$ for men was $77 \mathrm{mmHg}$ (SD. 9.1; and lower limit of normal at 62mmHg), while $\mathrm{PaO}_{2}$ for women was $73.5 \mathrm{mmHg}$ (SD. 8.4; lower limit of normal at 59.6mmHg), [23] and normal reference values reduce with age.[24] In practice, we estimated the acceptable normal values of $\mathrm{PaO}_{2}$ using the formula: normal $\mathrm{PaO}_{2}$ at sea level (in $\mathrm{mmHg}$ ) $=100$ minus the number of years over ago 40, as proposed.[25] For $\mathrm{SpO}_{2}$, we recommended $93 \%$ for men and $92 \%$ for women as the lower limit of normal. We also recommended $\mathrm{SpO}_{2} 95 \%$ or $96 \%$ as the highest target value, which is generally in keeping with the recommendation by Chinese CDC and the recently published guideline recommending of no higher than 96\%.[26] However, accuracy of $\mathrm{SpO}_{2}$ readings may be affected by factors such as low perfusion and the use of vasodilator,[27] so target values of $\mathrm{SpO}_{2}$ were set at the discretion of treating physician, and arterial blood gas analysis was used to adjust treatments (e.g., $\mathrm{FiO}_{2}$ and/or flow rate).

In our study, $\mathrm{FiO}_{2}$ values were maintained significantly lower in the early HFNC group (Figure 2). Post-hoc subgroup analysis in the late $\mathrm{HFNC}$ group revealed that $\mathrm{FiO}_{2}$ of survivors was significantly lower than that of the non-survivors (table 3), and initial targeted $\mathrm{SpO}_{2}$ was also relatively higher in the non-survivor subgroup (data not shown). In the current study, all the 
medRxiv preprint doi: https://doi.org/10.1101/2020.05.23.20111450; this version posted May 26, 2020. The copyright holder for this preprint (which was not certified by peer review) is the author/funder, who has granted medRxiv a license to display the preprint in perpetuity.

It is made available under a CC-BY-NC-ND 4.0 International license .

baseline characteristics and laboratory values were comparable between early and late HFNC groups.

There is evidence to show that airborne transmission with HFNC is minimal[11,28] and that risk of hospital-acquired infection did not increase with the use of HFNC provided there is good mask fitting.[29] However, the safety of HFNV in these patients is controversial given SARSCoV-2 virus is highly contagious.[30] Because of risks, all staff in ward or ICU care settings are strongly recommended/required to wear a disposable surgical cap, medical protective mask (N95), disposable medical protective uniform and disposable gloves with full-face respiratory protective devices when performing procedures like tracheal intubation.[31]

In conclusion, the application of HFNC in elderly patients ( $\geq 65$ years) with COVID-19, especially when used with conservative oxygen delivery, may prove to be a promising treatment modality for critically ill patients with acute ARDS in general, and of critically ill elderly COVID-19 patients in particular, although larger scale prospective studies are needed to confirm its effectiveness. Our current study provides evidence that application of HFNC earlier during the mild stage of ARDS may be associated with reduced need for mechanic ventilation and mortality in critically ill elderly patients with COVID-19 pneumonia. The fact that early application of HFNC was associated with shorter time duration of SARS-CoV-2 viral shedding may be of significance in reducing transmission.

\section{Clinical Perspectives}

- High-flow nasal cannula therapy (HFNC) is a major oxygen supporting therapy for severely ill patients, and is recommended for use in COVID-19 patients. However, study is lacking regarding the optimal timing of high-flow nasal cannula (HFNC) application among critically ill 
medRxiv preprint doi: https://doi.org/10.1101/2020.05.23.20111450; this version posted May 26, 2020. The copyright holder for this preprint (which was not certified by peer review) is the author/funder, who has granted medRxiv a license to display the preprint in perpetuity. It is made available under a CC-BY-NC-ND 4.0 International license .

elderly COVID-19 patients. We hypothesized that early application of HFNC for oxygen delivery in severely ill COVID-19 patients may facilitate patient recovery and reduce mortality.

- In this retrospective, multicenter cohort study involving 110 elderly patients with laboratoryconfirmed COVID-19, prognosis was much better in 38 patients who received HFNC when 200 $\mathrm{mmHg}<\mathrm{PaO} 2 / \mathrm{FiO} 2 \leq 300 \mathrm{mmHg}$, compared to 72 patients who received HFNC treatment when their $100 \mathrm{mmHg}<\mathrm{PaO} 2 / \mathrm{FiO} 2 \leq 200 \mathrm{mmHg}$. Early application of HFNC was associated shorter lengths of ICU and hospital stay and reduced mortality.

- HFNC should be considered early in treating elderly patients with COVID-19.

\section{Contributors}

LD and ZX had the idea for the study. ZX, LD and JT designed the study and have full access to all data in the study and take responsibility for the integrity of the data and the accuracy of the data analysis. SL, LZ, DL, CH, DZ, ZW, XS, and YZ collected the data. FJ, SL and DL performed data analysis. DAL, Z-YX, SW, CWC, HL and RLA participated in discussion/data interpretation. SL, FJ, DL and ZX drafted the manuscript. RLA, HL and ZX revised the final manuscript.

\section{Declaration of interests}

All authors declare no competing interests.

\section{Data sharing}


With the permission of the corresponding authors, the participant data without names and identifiers can be provided, but not the study protocol and statistical analysis plan. The data will be available for others to request after publication of study findings. The research team will provide an email address for communication once the data can be made public. The corresponding authors have the right to decide whether or not to share the data based on research objectives and plan provided.

\section{Acknowledgements}

The authors' work was supported by the grants from National Natural Science Foundation of China (NSFC 813000674, 81670770, 81970247). We acknowledge all health-care workers involved in the diagnosis and treatment of patients in Wuhan. We thank the patients and their families for providing requested data and information. 


\section{References:}

1 Munster VJ, Koopmans M, van Doremalen N, van Riel D and de Wit E. (2020) A Novel Coronavirus Emerging in China - Key Questions for Impact Assessment. N Engl J Med.382, 692-694.

2 Chen N, Zhou M, Dong X, Qu J, Gong F, Han Y, et al. (2020) Epidemiological and clinical characteristics of 99 cases of 2019 novel coronavirus pneumonia in Wuhan, China: a descriptive study. LANCET.395, 507-513.

3 Yang X, Yu Y, Xu J, Shu H, Xia J, Liu H, et al. (2020) Clinical course and outcomes of critically ill patients with SARS-CoV-2 pneumonia in Wuhan, China: a single-centered, retrospective, observational study. Lancet Respir Med. https://doi.org/10.1016 / S2213-2600 ( 20 ) 30079-5

Grasselli G, Pesenti A and Cecconi M. (2020) Critical Care Utilization for the COVID-19 Outbreak in Lombardy, Italy: Early Experience and Forecast During an Emergency Response. JAMA.https://doi.org/10.1001/jama.2020.4031

Bhatraju PK, Ghassemieh BJ, Nichols M, Kim R, Jerome KR, Nalla AK,et al. (2020) Covid-19 in Critically Ill Patients in the Seattle Region - Case Series. N Engl J Med.https://doi.org/10.1056 / NEJMoa2004500

Wu Z and McGoogan JM. (2020) Characteristics of and Important Lessons From the Coronavirus Disease 2019 (COVID-19) Outbreak in China: Summary of a Report of 72314 Cases From the Chinese Center for Disease Control and Prevention. JAMA. https://doi.org/10.1001 / jama. 2020.2648

Lu H. (2020) Drug treatment options for the 2019-new coronavirus (2019-nCoV). BioScience Trends.14, 69-71.

Wu C, Chen X, Cai Y, Xia J, Zhou X, Xu S, et al. (2020) Risk Factors Associated With Acute Respiratory Distress Syndrome and Death in Patients With Coronavirus Disease 2019 Pneumonia in Wuhan, China. JAMA Internal Medicine. https://doi.org/10.1001 / jamainternmed.2020.0994

Rochwerg B, Granton D, Wang DX, Helviz Y, Einav S, Frat JP, et al (2019) High flow nasal cannula compared with conventional oxygen therapy for acute hypoxemic respiratory failure: a systematic review and meta-analysis. Intensive Care Med.45, 563-572.

Liu Q, Zhu C, Lan C and Chen R. (2020) High-flow nasal cannula versus conventional oxygen therapy in patients with dyspnea and hypoxemia before hospitalization. Expert Rev Respir Med.14,425-433.

11 Lamontagne F and Angus DC. (2020) Toward Universal Deployable Guidelines for the Care of Patients With COVID-19. JAMA.https://doi.org/10.1001 / jama.2020.5110

Alhazzani W, Moller MH, Arabi YM, Loeb M, Gong MN, Fan E, et al. (2020) Surviving Sepsis Campaign: guidelines on the management of critically ill adults with Coronavirus Disease 2019 (COVID-19). Intensive Care Med.. https://doi.org/10.1007/s00134-020-06022-5

Huang C, Wang Y, Li X, Ren L, Zhao J, Hu Y, et al. (2020) Clinical features of patients infected with 2019 novel coronavirus in Wuhan, China. LANCET.395, 497-506.

14 Wang D, Hu B, Hu C, Zhu F, Liu X, Zhang J, et al. (2020) Clinical Characteristics of 138 Hospitalized Patients With 2019 Novel Coronavirus-Infected Pneumonia in Wuhan, China. JAMA. https://doi.org/10.1001 / jama.2020.1585 
medRxiv preprint doi: https://doi.org/10.1101/2020.05.23.20111450; this version posted May 26, 2020. The copyright holder for this preprint

(which was not certified by peer review) is the author/funder, who has granted medRxiv a license to display the preprint in perpetuity.

It is made available under a CC-BY-NC-ND 4.0 International license .

respiratory distress syndrome: the Berlin Definition. JAMA.307,2526-2533.

Khwaja A. (2012) KDIGO clinical practice guidelines for acute kidney injury. Nephron Clin Pract.120, c179-c184.

Bellani G, Laffey JG, Pham T, Fan E, Brochard L, Esteban A, et al. (2016) Epidemiology, Patterns of Care, and Mortality for Patients With Acute Respiratory Distress Syndrome in Intensive Care Units in 50 Countries. JAMA.315, 788-800.

Wang K, Zhao W, Li J, Shu W and Duan J. (2020) The experience of high-flow nasal cannula in hospitalized patients with 2019 novel coronavirus-infected pneumonia in two hospitals of Chongqing, China. Annals of Intensive Care.10, 37.https://doi.org/10.1186/s13613-020-00653-z

Mach WJ, Thimmesch AR, Pierce JT and Pierce JD. (2011) Consequences of hyperoxia and the toxicity of oxygen in the lung. Nurs Res Pract.2011, 260482. https://doi.org/10.1155/2011/260482

Liu Q, Zhou YH and Yang ZQ. (2016) The cytokine storm of severe influenza and development of immunomodulatory therapy. Cellular \& Molecular Immunology.13, 3-10.

Chu DK, Kim LH, Young PJ, Zamiri N, Almenawer SA, Jaeschke R, et al. (2018) Mortality and morbidity in acutely ill adults treated with liberal versus conservative oxygen therapy (IOTA): a systematic review and meta-analysis. LANCET.391, 1693-1705.

Arabi YM, Al-Omari A, Mandourah Y, Al-Hameed F, Sindi AA, Alraddadi B, et al. (2017) Critically Ill Patients With the Middle East Respiratory Syndrome: A Multicenter Retrospective Cohort Study. CRITICAL CARE MEDICINE.45, 1683-1695.

Klaestrup E, Trydal T, Pedersen JF, Larsen JM, Lundbye-Christensen S and Kristensen SR. (2011) Reference intervals and age and gender dependency for arterial blood gases and electrolytes in adults. CLINICAL CHEMISTRY AND LABORATORY MEDICINE.49, 1495-1500.

Hardie JA, Vollmer WM, Buist AS, Ellingsen I and Morkve O. (2004) Reference values for arterial blood gases in the elderly. CHEST.125, 2053-2060.

L. M. Rules on Oxygen Therapy. 2000.http://www.ucdenver.edu/academics/colleges/medicalschool/departments/medicine/intmed/imrp/CUR RICULUM/Documents/Oxygenation\%20and\%20oxygen\%20therapy.pdf. Accessed 15 Jan 2020.

Poston JT, Patel BK and Davis AM. (2020) Management of Critically Ill Adults With COVID-19. JAMA..https://doi.org/10.1001/jama.2020.4914.

Pretto JJ, Roebuck T, Beckert L and Hamilton G. (2014) Clinical use of pulse oximetry: official guidelines from the Thoracic Society of Australia and New Zealand. RESPIROLOGY.19, 38-46.

Leung C, Joynt GM, Gomersall CD, Wong WT, Lee A, Ling L, et al. (2019) Comparison of high-flow nasal cannula versus oxygen face mask for environmental bacterial contamination in critically ill pneumonia patients: a randomized controlled crossover trial. JOURNAL OF HOSPITAL INFECTION.101, 84-87.

29 Hui DS, Chow BK, Lo T, Tsang O, Ko FW, Ng SS, et al (2019) Exhaled air dispersion during high-flow nasal cannula therapy versus CPAP via different masks. EUROPEAN RESPIRATORY JOURNAL.53.https://doi.org/10.1183/13993003.02339-2018

30 Jiang F, Deng L, Zhang L, Cai Y, Cheung CW and Xia Z. (2020) Review of the Clinical Characteristics of Coronavirus Disease 2019 (COVID-19). JOURNAL OF GENERAL INTERNAL MEDICINE.https://doi.org/10.1007/s11606-020-05762-w

Jin YH, Cai L, Cheng ZS, Cheng H, Deng T, Fan YP, et al. (2020) A rapid advice guideline for the 
medRxiv preprint doi: https://doi.org/10.1101/2020.05.23.20111450; this version posted May 26, 2020. The copyright holder for this preprint (which was not certified by peer review) is the author/funder, who has granted medRxiv a license to display the preprint in perpetuity. It is made available under a CC-BY-NC-ND 4.0 International license .

diagnosis and treatment of 2019 novel coronavirus (2019-nCoV) infected pneumonia (standard version). Mil Med Res.7, 4.https://doi.org/10.1186/s40779-020-0233-6. 
medRxiv preprint doi: https://doi.org/10.1101/2020.05.23.20111450; this version posted May 26, 2020. The copyright holder for this preprint (which was not certified by peer review) is the author/funder, who has granted medRxiv a license to display the preprint in perpetuity.

\section{Figure legends}

Figure 1. Representative chest computed tomographic images of elderly patients with COVID-19 who received early or late High-flow nasal cannula (HFNC).

A-D: a 72 year old man with COVID-19 received early $\mathrm{HFNC}$ therapy when his $\mathrm{PaO}_{2} / \mathrm{FiO}_{2}$ was $256 \mathrm{mmHg}$. (A) Image obtained on day 1 showed small ground-glass opacity lesion (red arrow) in the middle lobe of the right lung; (B) image obtained on day 5 showed enlarged lesion in right lung and several small areas of new exudative lesions in outer basal segment of lower lobe of left lung; (C) image obtained on day 18 showed the lesion in the middle lobe of the right lung reduced more than $50 \%$, and clear interstitial lesions were found in the lower lobes of both lungs; (D) image obtained day 24 showed the lesions were further reduced and became lighter in density (red arrow). HFNC was discontinued on day 23, and this patient was discharged on Day 26.

E-F: a 68 year old man with COVID-19 received late HFNC oxygen therapy when his $\mathrm{PaO}_{2} / \mathrm{FiO}_{2}$ was $186 \mathrm{mmHg}$. (E) Image obtained on day 1 showed a few patchy exudative lesions and cord like fibrosis in bilateral lobes of both lungs (red arrow); (F) image obtained on day 7 showed original lesions were obviously increased, and parenchymal lesions (such as consolidation and air bronchogram) in the middle and lower lobes of right lung, as well as appearance of interstitial lesions in lower left lung; (G) image obtained on day 21 showed increased patchy exudative lesions and interstitial lesions with light density (a few reticular lung changes) in lower left lung; (F) image obtained on day 33 showed a few grid lung changes and subpleural lines in the right lower lobe. This patient required invasive mechanical ventilation on day 23, and died of cardiac arrest on day 36 after admission. 
Figure 2 Dynamic changes in major laboratory markers and SOFA score in elderly patients with COVID-19. Figure shows temporal changes in lymphocyte (A), lactate dehydrogenase (B), D-dimer (C), C-reactive protein (D), lactate (E), and SOFA score (F) after admission. COVID19=coronavirus disease 2019, SOFA score =Sequential Organ Failure Assessment score, HFNC=High-flow nasal cannula oxygen therapy. The horizontal lines represent the median value in each group.

Figure 3 Dynamic changes of PaO2/FiO2 and FiO2 and survival probability in patients with COVID-19. Figure shows temporal changes in $\mathrm{PaO}_{2} / \mathrm{FiO}_{2}(\mathrm{~A})$ and $\mathrm{FiO}_{2}(\mathrm{~B})$, and survival probability (C). COVID-19=coronavirus disease 2019, $\mathrm{PaO} 2 / \mathrm{FiO} 2=$ Ratio of arterial oxygen partial pressure to fraction inspired oxygen concentration, $\mathrm{FiO} 2=$ fraction inspired oxygen concentration. The horizontal lines represent the median value in each group in A and B. 
Table 1. Demographic, clinical characteristics and laboratory findings of the study cohort

\begin{tabular}{|c|c|c|c|c|}
\hline & $\begin{array}{l}\text { All patients } \\
(\mathrm{n}=110)\end{array}$ & $\begin{array}{l}\text { Early HFNC } \\
\text { group }(n=38)\end{array}$ & $\begin{array}{l}\text { Late HFNC group } \\
(n=72)\end{array}$ & $P$ value $^{\text {a }}$ \\
\hline Age, years & $71(68-78)$ & $69(68-77)$ & $72(69-78)$ & 0.086 \\
\hline Sex & & & & 0.853 \\
\hline Male & $65(59.1 \%)$ & $22(57.9 \%)$ & $43(59.7 \%)$ & .. \\
\hline Female & $45(40.9 \%)$ & $16(42.1 \%)$ & $29(40.3 \%)$ & .. \\
\hline Comorbidities & $87(79.1 \%)$ & $30(78.9 \%)$ & $57(79.1 \%)$ & 0.978 \\
\hline Hypertension & $57(51.8 \%)$ & $20(52.6 \%)$ & $37(51.4 \%)$ & 0.901 \\
\hline Cardiovascular disease & $27(24.5 \%)$ & $10(26.3 \%)$ & $17(23.6 \%)$ & 0.753 \\
\hline $\begin{array}{l}\text { Chronic pulmonary } \\
\text { disease }\end{array}$ & $22(20 \%)$ & $6(15.7 \%)$ & $16(22.2 \%)$ & 0.422 \\
\hline Diabetes & $20(18.2 \%)$ & $8(21.1 \%)$ & $12(16.6 \%)$ & 0.571 \\
\hline Chronic renal failure & $7(6.4 \%)$ & $2(5.3 \%)$ & $5(6.9 \%)$ & 0.946 \\
\hline Cerebrovascular disease & $7(6.4 \%)$ & $2(5.3 \%)$ & $5(6.9 \%)$ & 0.946 \\
\hline $\begin{array}{l}\text { Hepatitis or liver } \\
\text { cirrhosis }\end{array}$ & $5(4.5 \%)$ & $1(2.6 \%)$ & $4(5.5 \%)$ & 0.826 \\
\hline Malignancy tumor & $4(3.6 \%)$ & $1(2.6 \%)$ & $3(4.2 \%)$ & 0.899 \\
\hline \multicolumn{5}{|l|}{ First symptoms } \\
\hline Fever & $105(95.5 \%)$ & $36(94.7 \%)$ & $69(95.8 \%)$ & 0.826 \\
\hline Cough & $65(59.1 \%)$ & $21(55.3 \%)$ & $44(61.1 \%)$ & 0.553 \\
\hline Weakness & $23(20.9 \%)$ & $6(15.7 \%)$ & $17(23.6 \%)$ & 0.337 \\
\hline Sputum & $22(20 \%)$ & $8(21.1 \%)$ & $14(19.4 \%)$ & 0.841 \\
\hline Chest tightness & $15(13.6 \%)$ & $5(13.2 \%)$ & $10(13.8 \%)$ & 0.915 \\
\hline
\end{tabular}




$\begin{array}{lllll}\text { Dyspnea } & 9(8.2 \%) & 3(7.89 \%) & 6(8.33 \%) & 0.774 \\ \text { Dizziness } & 5(4.5 \%) & 1(2.6 \%) & 4(5.5 \%) & 0.826 \\ \text { Rhinorrhea } & 5(4.5 \%) & 1(2.6 \%) & 4(5.5 \%) & 0.826 \\ \text { Anorexia } & 4(3.6 \%) & 1(2.6 \%) & 3(4.2 \%) & 0.899 \\ \text { Vomiting } & 4(3.6 \%) & 1(2.6 \%) & 3(4.2 \%) & 0.899 \\ \text { Headache } & 4(3.6 \%) & 1(2.6 \%) & 3(4.2 \%) & 0.899 \\ \text { Diarrhoea } & 3(2.7 \%) & 0 & 3(4.2 \%) & 0.509\end{array}$

Laboratory findings on

admission

\begin{tabular}{|c|c|c|c|c|}
\hline Leukocyte count, $\times 10^{9} / \mathrm{L}$ & $5.6(4.1-7.2)$ & $5.8(4.1-9.6)$ & $5.6(4.3-6.9)$ & 0.547 \\
\hline $\begin{array}{l}\text { Lymphocyte count, } \\
\times 10^{9} / \mathrm{L}\end{array}$ & $0.8(0.6-1.0)$ & $0.8(0.7-0.9)$ & $0.8(0.6-1.1)$ & 0.310 \\
\hline Platelet count, $\times 10^{9} / \mathrm{L}$ & $\begin{array}{l}178.0(126.0- \\
214.5)\end{array}$ & $\begin{array}{l}178.0(108.5- \\
203.0)\end{array}$ & $\begin{array}{l}176.5(141.5- \\
232.8)\end{array}$ & 0.131 \\
\hline Haemoglobin, ng/mL & $10.9(10.1-11.9)$ & $10.9(9.8-11.4)$ & $11.2(10.2-12.5)$ & 0.573 \\
\hline C-reactive protein, $\mathrm{mg} / \mathrm{L}$ & $52.3(31.4-88.0)$ & $44.7(18.1-59.2)$ & $53.4(33.3-88.1)$ & 0.054 \\
\hline Procalcitonin, ng/mL & $0.09(0.04-0.25)$ & $0.09(0.03-0.28)$ & $0.09(0.04-0.24)$ & 0.910 \\
\hline $\begin{array}{l}\text { Alanine } \\
\text { aminotransferase, U/L }\end{array}$ & $18.1(15.1-21.3)$ & $17.8(14.8-20.2)$ & $18.5(15.2-21.3)$ & 0.540 \\
\hline $\begin{array}{l}\text { Aspartate } \\
\text { aminotransferase, U/L }\end{array}$ & $25.6(25.2-28.0)$ & $24.4(23.6-25.8)$ & $26.5(25.0-28.0)$ & 0.488 \\
\hline Total bilirubin, $\mu \mathrm{mol} / \mathrm{L}$ & $9.0(6.6-16.2)$ & $9.0(6.6-13.8)$ & $9.7(6.4-16.2)$ & 0.920 \\
\hline Albumin, g/L & $31.0(29.0-36.0)$ & $31.0(29.0-35.3)$ & $31.5(29.0-36.0)$ & 0.382 \\
\hline Blood glucose, mmol/L & $6.8(5.7-8.1)$ & $6.8(6.2-7.6)$ & $6.8(5.4-8.4)$ & 0.611 \\
\hline Serum creatinine & $73.0(61.2-97.0)$ & $69.0(53.5-90.3)$ & 80.7 (68.0-102.0) & 0.171 \\
\hline
\end{tabular}




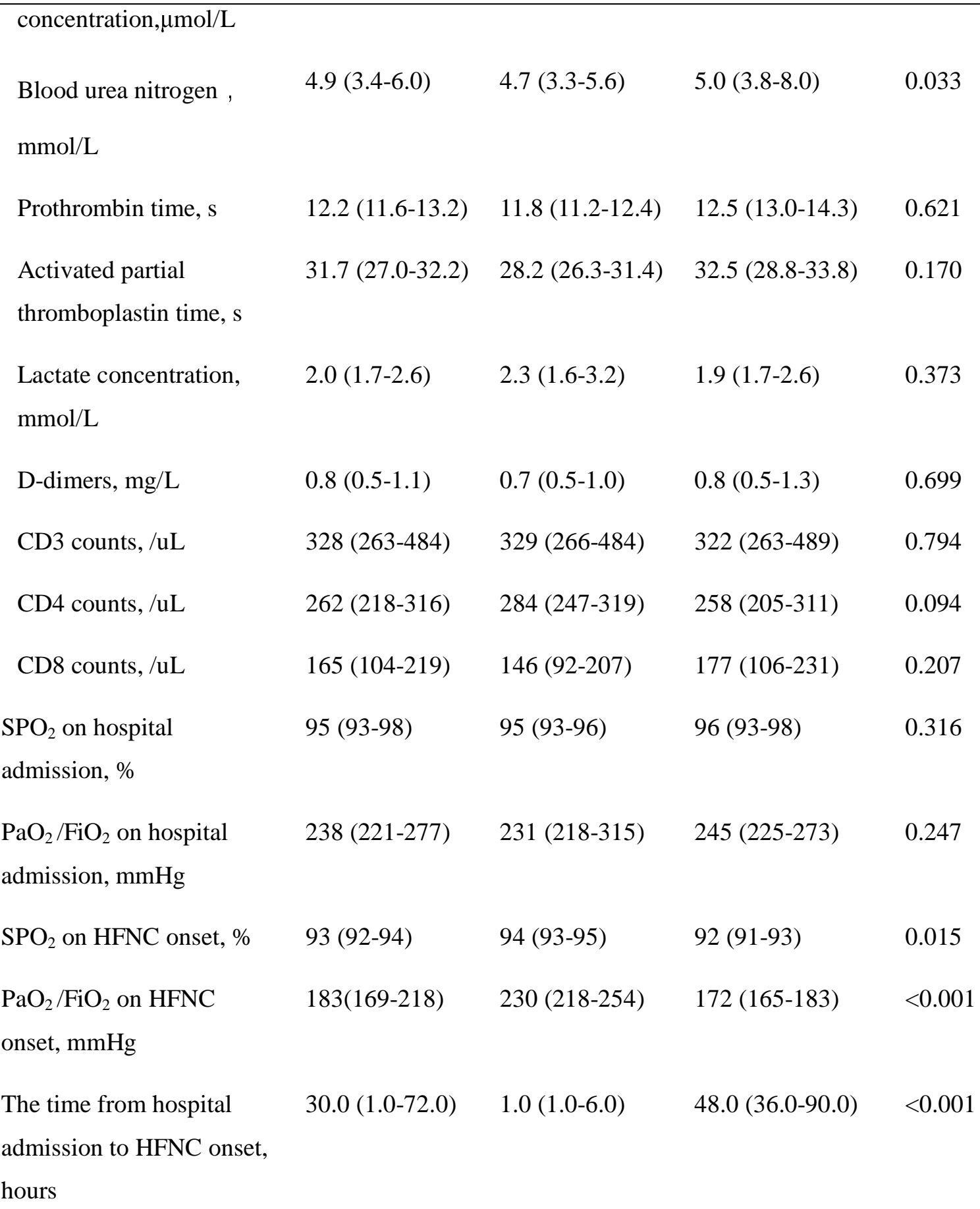

Data are median (IQR), $\mathrm{n}(\%)$, or $\mathrm{n} / \mathrm{N}(\%) . \mathrm{FiO}_{2}=$ fraction of inspired oxygen. HFNC=high flow nasal cannula. $\mathrm{PaO}_{2}=$ partial pressure of oxygen. $\mathrm{s}$ indicates second

${ }^{\mathrm{a}} P$ values indicate differences between early HFNC and late HFNC group.

$P<0.05$ was considered statistically significant. 
Table 2. Outcomes of the study cohort

\begin{tabular}{llll}
\hline All patients & Early HFNC & Late HFNC & P value $^{{ }^{a}}$ \\
$(\mathrm{n}=110)$ & group $(\mathrm{n}=38)$ & $\operatorname{group}(\mathrm{n}=72)$ &
\end{tabular}

\section{Treatment}

\begin{tabular}{|c|c|c|c|c|}
\hline Antiviral therapy & $100(100 \%)$ & $38(100 \%)$ & $72(100 \%)$ & NA \\
\hline Antibiotic therapy & $66(60 \%)$ & $20(52.6)$ & $46(63.9)$ & 0.027 \\
\hline Prone ventilation & $38(34.5 \%)$ & $3(7.9 \%)$ & $34(47.2 \%)$ & $<0.001$ \\
\hline Non-invasive mechanical ventilati & $24(21.8 \%)$ & $6(15.7 \%)$ & $18(25 \%)$ & 0.266 \\
\hline Invasive mechanical ventilation & $42(38.2 \%)$ & $4(10.5 \%)$ & $38(52.7 \%)$ & $<0.001$ \\
\hline ECMO & $7(6.4 \%)$ & $1(2.6 \%)$ & $6(8.3 \%)$ & 0.450 \\
\hline
\end{tabular}

\section{Complications}

$\begin{array}{lllll}\text { Secondary infection } & 51(46.3 \%) & 10(26.3 \%) & 41(56.9 \%) & 0.002 \\ \text { Severe ARDS } & 42(38.2 \%) & 4(10.5 \%) & 38(38.9 \%) & 0.037 \\ \text { Septic shock } & 18(16.4 \%) & 3(7.8 \%) & 15(20.8 \%) & 0.081 \\ \text { Cardiovascular event } & 13(11.8 \%) & 2(5.3 \%) & 11(15.3 \%) & 0.216 \\ \text { Acute kidney injury } & 6(5.4 \%) & 1(2.6 \%) & 5(6.9 \%) & 0.613 \\ \text { Cardiac arrest } & 3(2.7 \%) & 0 & 3(4.2 \%) & 0.518 \\ \text { Chest CT foci increasing } \geq 50 \% & 43(39.1 \%) & 8(21.1 \%) & 35(48.6 \%) & 0.004 \\ \text { The time from illness onset to } & 12(11-15) & 15(13-17) & 11(9-13) & <0.001 \\ \text { severe ARDS, days } & & & & <0.001 \\ \text { The time from illness onset to } & 11(8-14) & 14(10-16) & 11(8-13) & <0.001 \\ \text { ICU admission, days } & & & & \\ \text { ICU admission } & & & & \\ \end{array}$




\begin{tabular}{|c|c|c|c|c|}
\hline ICU stay $\geq 7$ days & $57(51.8 \%)$ & $14(36.8 \%)$ & $43(59.7 \%)$ & 0.022 \\
\hline Length of ICU stay, days & $17(12-22)$ & $12(10-15)$ & $18(13-22)$ & $<0.001$ \\
\hline Length of stay, days & $27(16-32)$ & $16(15-22)$ & $30(27-33)$ & $<0.001$ \\
\hline Duration of viral shedding after & $16(13-21)$ & $12(9-15)$ & $18(15-25)$ & $<0.001$ \\
\hline \multicolumn{5}{|l|}{ illness onset, days } \\
\hline \multicolumn{5}{|l|}{$\mathrm{FiO}_{2}$ during hospitalization } \\
\hline $100 \%$ more than 72 hours & $4(3.6 \%)$ & 0 & $4(5.5 \%)$ & 0.345 \\
\hline \multicolumn{5}{|l|}{ continuously } \\
\hline$\geq 80 \%$ more than 72 hours & $23(22.7 \%)$ & $3(7.9 \%)$ & $20(27.8 \%)$ & 0.015 \\
\hline \multicolumn{5}{|l|}{ continuously } \\
\hline$\geq 60 \%$ more than 72 hours & $40(36.4 \%)$ & $4(10.5 \%)$ & $36(50 \%)$ & $<0.001$ \\
\hline \multicolumn{5}{|l|}{ continuously } \\
\hline Prognosis & & & & 0.002 \\
\hline Discharge & $86(78.2 \%)$ & $36(94.7 \%)$ & $50(69.4 \%)$ & .. \\
\hline Death & $24(21.8 \%)$ & $2(5.3 \%)$ & $22(30.6 \%)$ & .. \\
\hline
\end{tabular}

Data are median (IQR), $\mathrm{n}(\%)$, or $\mathrm{n} / \mathrm{N}(\%)$. $\mathrm{ECMO}=$ extracorporeal membrane oxygenation. $\mathrm{FiO}_{2}=$ fraction of inspired oxygen. HFNC=high flow nasal cannula. $\mathrm{ICU}=$ intensive care unit. $\mathrm{PaO} 2=$ partial pressure of oxygen. NA=not applicable.

${ }^{a} P$ values indicate differences between early HFNC and late HFNC group.

$P<0.05$ was considered statistically significant. 
Table 3. Clinical measures of 72 elderly patients with COVID-19 who received late HFNC group

\begin{tabular}{|c|c|c|c|c|}
\hline Clinical measures & $\begin{array}{l}\text { Total } \\
(n=72)\end{array}$ & $\begin{array}{l}\text { Non-survivors } \\
(\mathrm{n}=22)\end{array}$ & $\begin{array}{l}\text { Survivors } \\
(\mathrm{n}=50)\end{array}$ & $P$ value $^{\mathrm{a}}$ \\
\hline Heart rate, beats per min & $92(68-139)$ & $93(62-141)$ & $91(65-132)$ & 0.287 \\
\hline $\begin{array}{l}\text { Systolic blood pressure on } \\
\text { admission, } \mathrm{mmHg}\end{array}$ & $134(115-158)$ & $138(110-163)$ & $130(105-165)$ & 0.565 \\
\hline $\begin{array}{l}\text { Diastolic blood pressure on } \\
\text { admission, } \mathrm{mmHg}\end{array}$ & $75(66-115)$ & $77(63-115)$ & $75(65-110)$ & 0.431 \\
\hline SOFA score on admission & $4(3-6)$ & $5(3-7)$ & $4(3-6)$ & 0.127 \\
\hline APECHE $\square$ score on admission & $14(12-19)$ & $15(12-19)$ & $14(12-17)$ & 0.602 \\
\hline Comorbidities per person & $1.4(0.8-1.6)$ & $1.6(0.9-1.7)$ & $1.3(0.6-1.6)$ & 0.211 \\
\hline $\begin{array}{l}\text { Haemoglobin concentration on } \\
\text { admission, } g / L\end{array}$ & $125(97-136)$ & $123(92-138)$ & $125(98-143)$ & 0.341 \\
\hline $\begin{array}{l}\text { Lymphocyte count on } \\
\text { admission, } \times 10^{9} / \mathrm{L}\end{array}$ & $0.75(0.35-1.65)$ & $0.73(0.32-1.63)$ & $0.76(0.39-1.71)$ & 0.791 \\
\hline $\begin{array}{l}\text { Platelet count on admission, } \\
\times 10^{9} / \mathrm{L}\end{array}$ & $165(123-223)$ & $165(121-231)$ & $167(126-226)$ & 0.463 \\
\hline $\begin{array}{l}\text { Total bilirubin concentration on } \\
\text { admission, } \mu \mathrm{mol} / \mathrm{L}\end{array}$ & $9.3(6.7-15.6)$ & $9.6(6.4-16.2)$ & $9.2(6.5-14.3)$ & 0.358 \\
\hline $\begin{array}{l}\text { Serum creatinine concentration } \\
\text { on admission, } \mu \mathrm{mol} / \mathrm{L}\end{array}$ & $78.7(55.6-101.2)$ & $83.5(70.2-102)$ & $71.2(53.3-91.5)$ & 0.212 \\
\hline $\begin{array}{l}\text { Lactate concentration on } \\
\text { admission, } \mathrm{mmol} / \mathrm{L}\end{array}$ & $1.7(1.5-3.2)$ & $1.7(1.3-3.1)$ & $1.6(1.3-3.2)$ & 0.411 \\
\hline $\begin{array}{l}\text { Ratio of } \mathrm{PaO}_{2} \text { to } \mathrm{FiO}_{2}, \mathrm{mmHg} \\
\text { on admission }\end{array}$ & $173(155-197)$ & $174(132-198)$ & $172(152-195)$ & 0.637 \\
\hline Invasive Mechanical ventilation & $38(52.7 \%)$ & $22(100 \%)$ & $16(32 \%)$ & $<0.001$ \\
\hline \multicolumn{5}{|l|}{$\mathrm{FiO}_{2}$ during hospitalization } \\
\hline $\begin{array}{l}100 \% \text { more than } 72 \text { hours } \\
\text { continuously, } \mathrm{n}\end{array}$ & $4(5.5 \%)$ & $4(18.1 \%)$ & 0 & 0.011 \\
\hline $\begin{array}{l}>80 \% \text { more than } 72 \text { hours } \\
\text { continuously, } \mathrm{n}\end{array}$ & $16(22.2 \%)$ & $12(54.5 \%)$ & $4(8 \%)$ & $<0.001$ \\
\hline
\end{tabular}


medRxiv preprint doi: https://doi.org/10.1101/2020.05.23.20111450; this version posted May 26, 2020. The copyright holder for this preprint (which was not certified by peer review) is the author/funder, who has granted medRxiv a license to display the preprint in perpetuity. It is made available under a CC-BY-NC-ND 4.0 International license.

$>60 \%$ more than 72 hours

$32(44.4 \%)$

22 (100\%)

$12(24 \%)$

$<0.001$

continuously, $\mathrm{n}$

Data are median (IQR), $\mathrm{n}(\%)$, or $\mathrm{n} / \mathrm{N}(\%)$. $\mathrm{FiO}_{2}=$ fraction of inspired oxygen. HFNC=high flow nasal cannula. $\mathrm{PaO}_{2}=$ partial pressure of oxygen.

${ }^{\text {a } P}$ values indicate differences between Non-survivors and Survivors.

$P<0.05$ was considered statistically significant. 

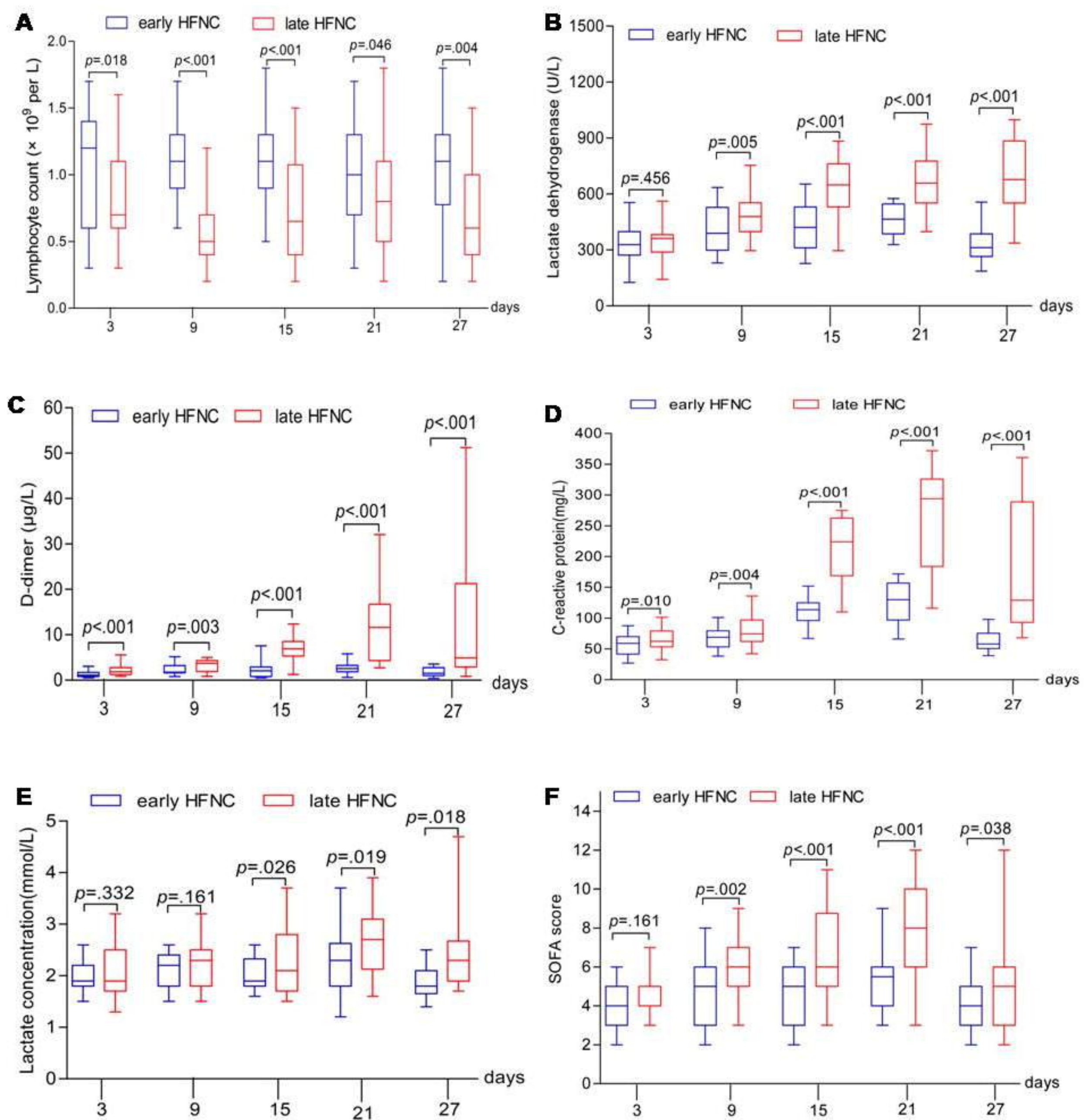

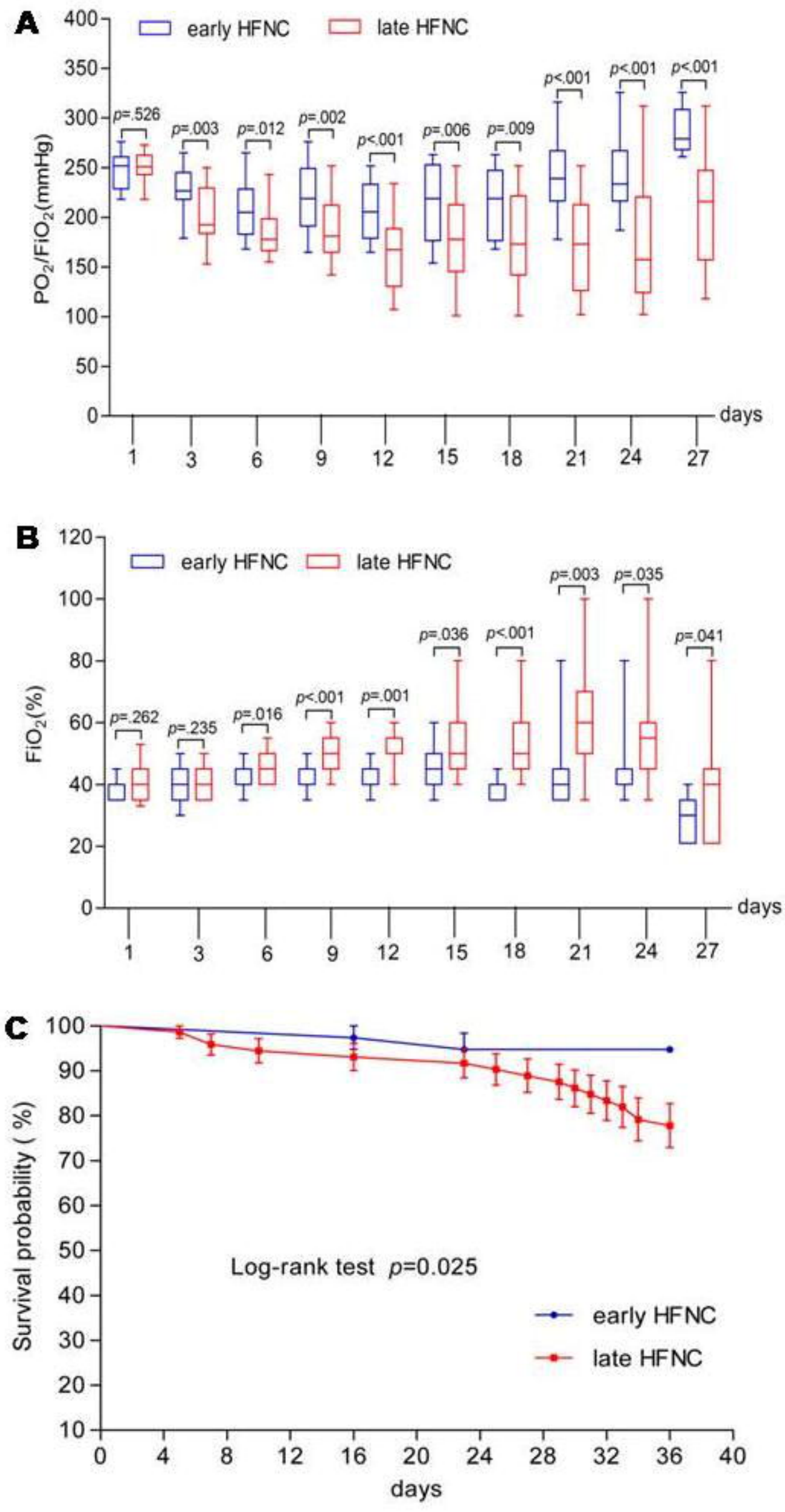